\title{
La educación popular \\ latinoamericana. Historia y claves éticas, políticas y pedagógicas de Oscar Jara Holliday
}

Jara Holliday, Oscar. 2018. La educación popular latinoamericana. Historia y claves éticas, políticas y pedagógicas. San José: Alforja.

\section{Luis Andrés Sanabria Zaniboni}

Costarricense. Licenciado en Relaciones Internacionales por la Universidad Nacional de Costa Rica. Investiga sobre epistemologías del sur, metodologías participativas y los desafíos de la Educación Popular en la formación política. Actualmente trabaja en el Centro de Estudios y Publicaciones Alforja de Costa Rica y colabora con el Consejo de Educación Popular de América Latina y el Caribe (CEAAL).

Correo electrónico: luis@cepalforja.org.

"Los hombres nadan para alcanzar las grandes piedras, cortando el río, llegan a ellas y duermen allí, porque de ningún otro lugar se oye mejor el sonido del agua" (Arguedas, 2011, p. 35-36)

Los ríos que conforman los pensamientos y prácticas de liberación de Nuestramerica provienen de muchas vertientes, y muchas han sido las personas que han tomado tiempo para escuchar el caudal de estas corrientes que le han dado forma a los distintos procesos que han llenado de sentidos a nuestras historias de emancipación.

Sin duda alguna, la Educación Popular representa uno de estos ríos, que con su andar ha moldeado nuestro pensar-hacer. En su largo trayecto ha recorrido nuestras montañas, valles y costas, irrigando a nuestros pueblos con las fuerzas de las esperanzas de cambio y transformación, y desde distintas direcciones ha contribuido a la construcción de esos otros mundos posibles.

Muchas personas han contribuido a este recorrido. El libro La Educación Popular Latinoamericana, Historia y claves éticas políticas y pedagógicas viene a dar cuenta de la mayoría de ellas, de sus trayectorias, pero también de sus ideas y propuestas. Su autor Oscar Jara Holliday es sin duda juez y parte. Como señala en el prólogo Carlos Rodríguez Brandão, la historia personal del autor se intrinca con las historias de la Educación Popular, lo que lo convierte no sólo en testigo privilegiado, sino también en uno de sus protagonistas. 
Esto, lejos de ser una desventaja, le permitió sentir y vivir las diversas corrientes de vidas y pensamientos que han nutrido los procesos de Educación Popular, así como le posibilitó volver a mirar estos procesos desde una mirada que interpela y pregunta. Esto hace de este libro un apasionante recorrido por las venas abiertas de una América Latina y el Caribe despiertos, siempre en búsqueda y construcción de su propia libertad. En otras palabras, Lo que nos plantea Oscar Jara no sólo es una invitación a mirar, sino y sobre todo, una provocación a un hacer.

No conformándose con un recorrido descriptivo, el autor nos desafía con algunas ideas provocadoras para interpelar la Educación Popular desde los tiempos presentes que nos atraviesan, porque, como él sostiene, la Educación Popular no sólo se expresa en su dimensión educativa y pedagógica, sino que es conjuntamente a su propuesta ética y política donde encontramos realmente el compromiso por la transformación de nuestra realidad.

Esto lo plantea porque nos recuerda que la Educación Popular -tanto fenómeno socio-cultural como concepción educativa- ha estado vinculada desde sus inicios a los procesos de organización y lucha de nuestros pueblos, lo que quiere decir que son procesos que responden a sus contextos, y son los sujetos, los y las protagonistas que aprenden a leer críticamente desde y para sus propias situaciones, necesidades y esperanzas.

Entonces partiendo de sujetos y contextos concretos, estos procesos de Educación Popular se constituyen como prácticas y políticas heterogéneas que tienen como corazón permitir no sólo la lectura y comprensión crítica, sino también la transformación de su propia realidad.

Y es en la confluencias de diálogos entre muchas de estas experiencias de transformación, donde la Educación Popular ha construido también los espacios de encuentro y reflexión que han convocado desde organizaciones campesinas, hasta Facultades Universitarias, lo que le ha permitido reencontrarse al día de hoy con un acumulado teórico y político propio, y que precisamente este libro recoge y proyecta con fuerza.

Sin duda alguna, la Educación Popular gracias a su acumulado histórico, pero también a la vitalidad de sus debates y prácticas, se constituye por mérito propio como una propuesta ética, política y pedagógica nacida en América Latina y el Caribe, siempre huyendo de ser "una", sino cultivándose en la diversidad de contextos, territorios y tiempos, pero sin renunciar al compromiso con esa mirada crítica por la transformación democrática y democratizadora de todas las relaciones de poder.

Su autor Oscar Jara, como ya lo recordaba José María Arguedas (2001), es uno de esos hombres que ha sabido nadar y encontrar en esos ríos profundos de Nuestramerica el mejor lugar para escuchar los sonidos de su caudal, y con el paso del tiempo, volver a sus fuentes originales, para darnos cuenta de todo lo aprendido y sentido, no como mero recuento, sino como historia viva, comprometida con la sabiduría popular, que entre exilios y abrazos in- 
conclusos, supo sembrar la solidaridad y esperanza en tiempos difíciles y cosechar ahí la amistad y el amor.

Así que leer La Educación Popular Latinoamérica: Historia y claves éticas, políticas y pedagógicas de Oscar Jara es más que una invitación, es una provocación para mojarnos en los procesos Latinoamericanos y Caribeños por construir esa educación que responda a la sociedad que queremos y soñamos.

\section{Fuentes de información consultada}

Arguedas, José M. 2001. Los ríos profundos. Lima, Perú: Editorial Estruendomundo. 